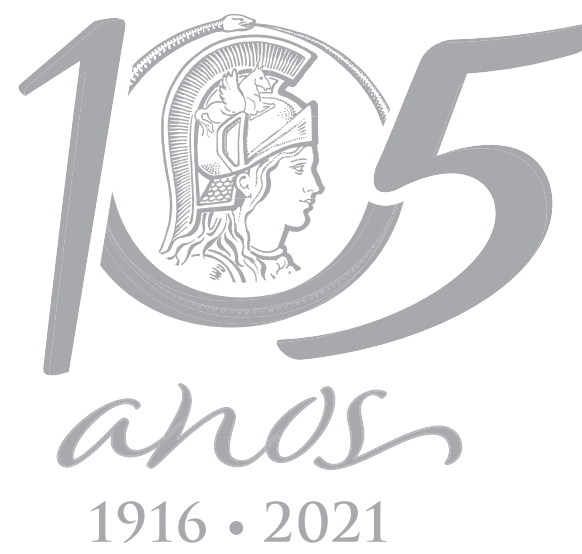

\title{
ECOSYSTEMS
}

\section{Functional traits of three major invasive grasses in a threatened tropical mountain grassland}

\author{
GERALDO W. FERNANDES, LUCAS B.S. TAMEIRÃO, ADRIANA R. COSTA, DANIELE G. \\ RIBEIRO, MICHELE N. NEVES, BETÂNIA G. SOUZA E BRITO \& DANIEL NEGREIROS
}

\begin{abstract}
The native flora of the Brazilian rupestrian grassland (campos rupestres) is threatened by the spread of invasive grasses. In this study, we evaluated the effect of habitat on the functional traits and CSR ecological strategies of three invasive alien grasses occurring both in the ironstone (IRG) and quartzitic ( $Q R G)$ rupestrian grassland habitats. Although in both habitats the invasive species predominantly showed a stress-tolerant strategy, they exhibited distinct degrees of stress-tolerance and slightly differences in functional traits values in the IRG compared to the QRG. Habitat type distinctly influenced invasive grasses functional traits and ecological strategies, revealing a species-specific pattern.
\end{abstract}

Key words: Biological invasion, campos rupestres, CSR strategy, leaf economics spectrum, Poaceae, rupestrian grasslands.

\section{INTRODUCTION}

From north to south of the American continent and from Europe to Oceania there are reports of biological invasions, mainly by African grass species (Pivello et al. 1999, McIntyre et al. 2005, Dawson et al. 2011, Stokes et al. 2011). In Brazil, these grasses are widely distributed, colonizing a large part of the native biomes (Filgueiras et al. 2015, Shirasuna 2015). When the environment is already threatened by other factors, biological invasions represent a serious aggravating factor, for competing for area and resources with native species, as well as simplifying the environment and hindering its restoration (D'Antonio \& Vitousek 1992).

The campo rupestre occurs generally at altitudes above $900 \mathrm{~m}$ in the Espinhaço mountains, with grasses, herbs and shrubs dominating the xeromorphic vegetation that grows on soils that are shallow, acidic and poor in nutrients (Fernandes 2016, Silveira et al. 2016). Throughout the Espinhaço mountain range, native grasses form a dominant and conspicuous matrix (Giulietti et al. 1997, Le Stradic et al. 2015). Although there are some studies on the functional traits of plants in the campo rupestre (e.g., Negreiros et al. 2014, Carmo \& Jacobi 2016), little is known about the functional characteristics of invasive species in this environment.

\section{Development}

Two types of substrate predominate in the Espinhaço mountain range, distinguishing the ironstone rupestrian grassland (IRG) with high levels of metals (primarily manganese and iron), from quartzitic rupestrian grassland (QRG) with high aluminum content. Both campo rupestre habitats are threatened because, in addition to mining and increasing urbanization, biological invasions are aggravated by the presence of African grasses of the genera Urochloa and Melinis already established in areas undergoing 
rapid anthropization (Jacobi et al. 2007, Viana \& Lombardi 2007, Barbosa et al. 2010, Fernandes et al. 2016, 2018).

A widely known tool to evaluate the functional character of plants is the ecological strategy scheme CSR (C: competitive, S: stresstolerant, R: ruderal, Grime 1977, Grime \& Pierce 2012), in which a set of functional traits delimits strategies of survival in plants. In the present study we used the campo rupestre as a natural experiment to test, for the first time, the effect of the habitat on the functional traits of three species of invasive African grasses present in both quartzitic ( $Q R G$ ) and ironstone (IRG) habitat types. The goal of this study was to: 1) Identify CSR strategies of invasive and native Poaceae species, and 2) Test the hypothesis that functional differences in traits and CSR ecological strategies are evident for plants invading ironstone cf. quartzitic grasslands.

The species sampled in the present study were located on the roadsides crossing conservation units in two distinct campo rupestre habitats. Both sampled areas are located in the southern portion of Espinhaço mountain range, southeastern Brazil. The QRG area is located in Serra do Cipó (19¹7'46"S, 43³5'28"W, 1200 meters a.s.l.), while the IRG area in Serra do

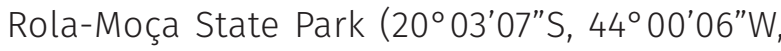
1430 meters a.s.l.). The three species of invasive exotic grasses sampled - Melinis repens (Willd.) Zizka, Melinis minutiflora P. Beauv, and Urochloa decumbens (Stapf) R.D. Webster - are native to the African continent and were disseminated in Brazil as pastures for pasture improvement (Pivello et al. 1999, Saint-Hilaire 2011 [1837]). All the three studied invasive species are perennial grasses described as drought tolerant, with high biomass production, resistance to biomass destruction (e.g. grazing and mowing) and high invasive potential (Bianco et al. 2005, Fagundes et al. 2006, Serrano-Cárdenas et al. 2009, Pereira et al. 2011, Conceição et al. 2015).

For functional trait measurements, 10 individuals were collected from each of the three invasive grass species, at least 20 meters apart to avoid the collection of genetically identical individuals. To determine the three foliar characteristics necessary for calculations of CSR strategies (i.e., specific leaf area, leaf dry matter content, and leaf area), each individual was collected with part of their root system in the field, to prevent the desiccation of the foliar material, leaf material collection was avoided at the time of greatest solar incidence (10 A.M. to 3 P.M.) (see Negreiros et al. 2014 for details). Canopy height was measured in field. All procedures followed the protocols described in Perez-Harguindeguy et al. (2013). To determine the relative importance of ecological CSR strategies, the "StrateFy" calculation sp readsheet was used, available in Pierce et al. (2017). This spreadsheet allows species to be compared against the multivariate space delimited by the global dataset (that involved 3068 species from all major world biomes). The data on native Poaceae - Axonopus sp. P. Beauv., Echinolaena inflexa (Poir.) Chase, Mesosetum loliiforme (Hochst.) Chase, Trichanthecium cyanescens (Nees ex Trin.) Zuloaga \& Morrone, Paspalum erianthum Nees ex Trin., Paspalum pectinatum Nees ex Trin. and Trachypogon spicatus (L.f.) Kuntze - were obtained from Negreiros et al. (2014).

The mean values of the functional traits and ecological CSR strategies of each invasive species were compared between the QRG and the IRG using the non-parametric Mann-Whitney test, since most of the variables were neither normal nor normalizable through transformations (Quinn \& Keough 2002). We used a two-way ANOVA to compare the trait variation of species 
between habitats, with 'species' and 'habitat' as fixed factors (Gotelli \& Elisson 2004).

In both types of campos rupestre habitats (IRG and QRG) the ecological strategies of the three invasive grasseswere predominantlystresstolerant, similar to the native Poaceae species of these environments, but with a slightly higher ruderality degree (Fig. 1). However, habitat type had a distinct influence on the functional traits and ecological strategies of the three species studied, revealing a species-specific pattern. The three studied species showed distinct functional traits and CSR strategies in the IRG compared to the QRG. Species and habitat type are together important factors driving trait variation in four of the six functional traits evaluated (Table I). The effect of interaction term is strong for SLA, stress tolerance and ruderality, but their variations depend more on species than on habitat type. Habitat effect is significant for LDMC but the species and interaction term are not. Both species and habitat effects are significant for canopy height, but since the interaction term is not significant, these effects can be seen as strictly additives. The effect of interaction term is strong for competitiveness, as the level of competitiveness depends on habitat type and species.

In the IRG, M. minutiflora presented more acquisitive leaf economy (sensu Wright et al. 2004; Fig. 2a), lower competitiveness (Fig. 2d) and greater ruderality (Fig. 2f) compared to

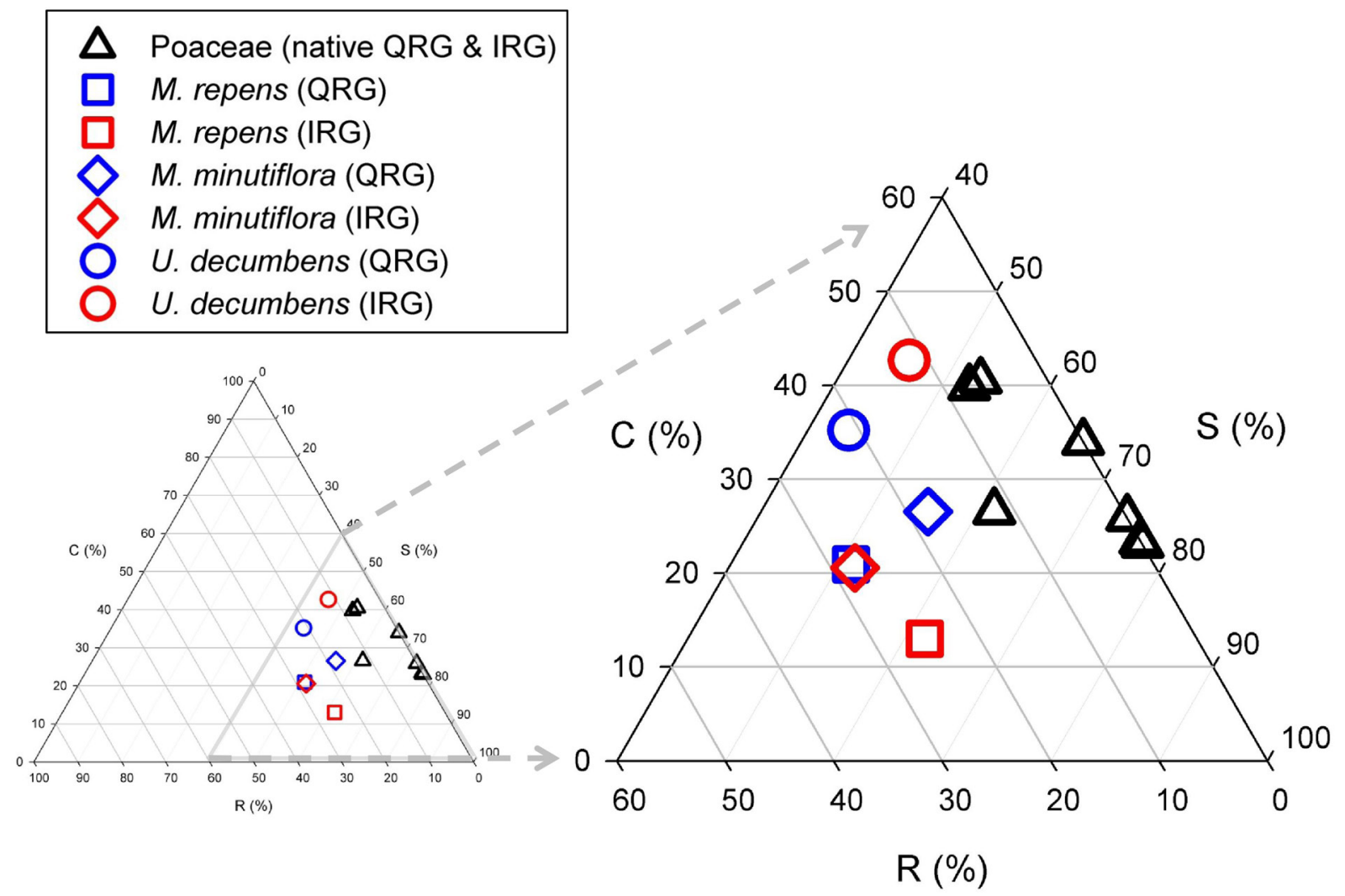

Figure 1. Triangular space representing the relative intensity of CSR strategies of three species of invasive exotic grasses and seven species of native grasses found in the ironstone rupestrian grasslands (IRG) and the quartzitic rupestrian grasslands (QRG). Colored symbols represent the mean of individuals of each exotic species $(\mathrm{N}=10)$. The data of native grasses were obtained from Negreiros et al. (2014), and the triangular symbols represent the mean of each native species $(\mathrm{N}=10)$. 
plants in the QRG. In contrast, in the IRG the congeneric $M$. repens presented less acquisitive leaf economy (Fig. 2b), lower competitiveness (Fig. 2d) and higher stress-tolerance (Fig. 2e) compared to plants in the QRG. On the other hand, U. decumbens plants in the IRG showed a less acquisitive leaf economy (Fig. 2a-b), with larger size (Fig. 2C), higher competitiveness (Fig. 2d) and lower ruderality (Fig. 2f) compared to plants in the QRG.

Urochloa decumbens was the species with the most drastic variations between the two habitats, with significant differences in five of the six traits evaluated. In the IRG individuals of this species grew more slowly, investing in more resistant and durable structures, reaching an average size 30\% greater than the QRG. On the other hand, M. minutiflora exhibited an opposite pattern to $U$. decumbens, showing more acquisitive and ruderal characteristics in the IRG. Melinis repens was the only species that exhibited distinct stress-tolerance values in the two habitats. The individuals of $M$. repens showed more stress-tolerance in the IRG. Although $M$. repens is little mentioned as invasive in the cerrado and campo rupestre ecosystems, in the present study it also showed great similarity to the community of native grasses. Thus, there is a risk of this species expanding its population and causing damage to this ecosystem.

Concluding, we have showed that invasive species are relatively more ruderal than native Poaceae species, in terms of CSR theory. We also found evidence to confirm our hypothesis that functional traits and CSR strategies differ among habitats. The three invasive grasses species may exhibit a degree of phenotypic plasticity that lead to functional differences depending on the habitat type. The functional traits of the three exotic grasses are typical of invasive species and favor their performance, establishment and dispersal in the environment (Rejmánek \& Richardson 1996, Everett 2000). Invaders with more acquisitive economics have greater potential to exert great impacts on the ecosystem, such as changing the balance between diversity and productivity (Levine et al. 2003, van Kleunen et al. 2010, Vilá et al. 2011). The presence of invasive species in degraded areas and roadsides in areas of both quartzitic and ironstone campos rupestres should be viewed with great concern, as there are indications that there is an imminent risk that these plants will dominate the local vegetation over time (Fernandes \& Barbosa 2013, Fernandes et al. 2015).

Table I. Results of the two-way analysis of variance. SLA: specific leaf area; LDMC: leaf dry matter content; Height: canopy height; C: competitiveness; S: stress-tolerance; R: ruderality. Bold $p$-values indicate significance $(p<0.05)$.

\begin{tabular}{|c|c|c|c|c|c|c|}
\hline \multirow{2}{*}{} & \multicolumn{2}{|c|}{ Species } & \multicolumn{2}{c|}{ Habitat } & \multicolumn{2}{c|}{ Interaction } \\
\cline { 2 - 7 } & $\mathbf{F}$ & $\mathbf{p}$ & $\mathbf{F}$ & $\mathbf{p}$ & $\mathbf{F}$ & $\mathbf{p}$ \\
\hline SLA & 5.472 & $\mathbf{0 . 0 0 7}$ & 3.001 & 0.089 & 5.915 & $\mathbf{0 . 0 0 5}$ \\
\hline LDMC & 0.725 & 0.489 & 30.44 & $\mathbf{0 . 0 0 1}$ & 11.61 & 0.064 \\
\hline Height & 55.4 & $\mathbf{0 . 0 0 0}$ & 27.02 & $\mathbf{0 . 0 0 3}$ & 11.41 & 0.073 \\
\hline C & 217.8 & $\mathbf{0 . 0 0 0}$ & 6.009 & $\mathbf{0 . 0 1 7}$ & 30.4 & $\mathbf{0 . 0 0 0}$ \\
\hline S & 14.64 & $\mathbf{0 . 0 0 8}$ & 2.836 & 0.098 & 6.56 & $\mathbf{0 . 0 0 3}$ \\
\hline R & 9.399 & $\mathbf{0 . 0 0 0}$ & 0.348 & 0.557 & 10.73 & $\mathbf{0 . 0 0 0}$ \\
\hline
\end{tabular}



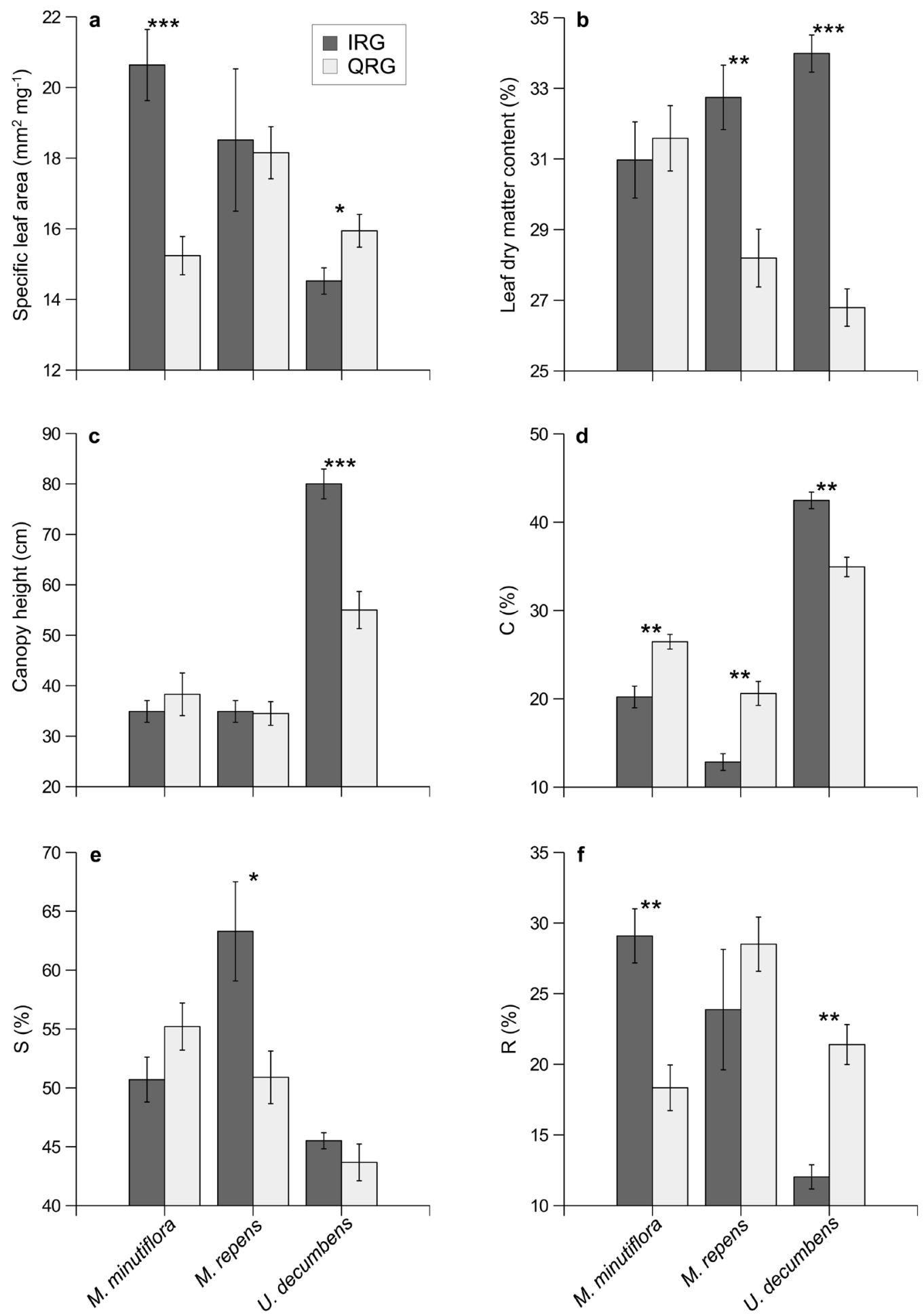

Figure 2. Comparison of the functional traits and ecological strategies of each exotic invasive species in ironstone rupestrian grasslands (IRG) and the quartzitic rupestrian grasslands (QRG). Asterisks indicate significant difference for each species between IRG and QRG, according to the Mann-Whitney test: ${ }^{*} p<0.05$; ${ }^{* *} p<0.01$; ${ }^{* * *} p<0.001$. C: competitiveness; S: stress-tolerance; R: ruderality. Bars represent the mean and the vertical line the standard error ( $\mathrm{N}=10$ individuals). 


\section{Acknowledgments}

We thank J. C. da Silveira for the availability and great laboratorial support, Reserva Vellozia, Instituto Estadual de Florestas (IEF) and Parque Estadual Serra do RolaMoça for logistical support. We are also grateful to Coordenação de Aperfeiçoamento de Pessoal de Nivel Superior (CAPES) for supporting the Master's scholarship of LBST, and Conselho Nacional de Desenvolvimento Científico e Tecnológico (CNPq), Fundação de Amparo a Pesquisa do Estado de Minas Gerais (FAPEMIG)/Vale, and Anglo American for financial support to the research group.

\section{REFERENCES}

BARBOSA NPU, FERNANDES GW, CARNEIRO MAA \& JÚNIOR LAC. 2010. Distribution of non-native invasive species and soil properties in proximity to paved roads and unpaved roads in a quartzitic mountainous grassland of southeastern Brazil (rupestrian fields). Biol Invasions 12: 3745-3755.

BIANCO S, TONHÃO MAR \& PITELLI RA. 2005. Crescimento e nutrição mineral de capim-braquiária. Planta Daninha 23: 423-428.

CARMO FF \& JACOBI CM. 2016. Diversity and plant traitsoil relationships among rock outcrops in the Brazilian Atlantic rainforest. Plant Soil 403: 7-20.

CONCEIÇÃO AA ET AL. 2015. Vegetação endêmica e espécie invasora em campos rupestres de áreas garimpadas. Rodriguésia 66: 675-682.

D'ANTONIO CM \& VITOUSEK PM. 1992. Biological invasions by exotic grasses, the grass/fire cycle, and global change. Annu Rev Ecol Syst 23: 63-87.

DAWSON W, FISCHER M \& VAN KLEUNEN M. 2011. The maximum relative growth rate of common UK plant species is positively associated with their global invasiveness. Global Ecol Biogeogr 20: 299-306.

EVERETT RA. 2000. Patterns and pathways of biological invasions. Trends Ecol Evol 15: 177-178.

FAGUNDES JL ET AL 2006. Características morfogênicas e estruturais do capim-braquiária em pastagem adubada com nitrogênio avaliada nas quatro estações do ano. Rev Bras Zootecn 35: 22-23.

FERNANDES GW. 2016. Ecology and conservation of mountaintop grasslands in Brazil. Switzerland, Springer, $567 \mathrm{p}$.

FERNANDES GW \& BARBOSA NPU. 2013. Bombas-relógio que ameaçam a natureza. Sci Am Brasil 135: 60-61.
FERNANDES GW ET AL. 2018. The deadly route to collapse and the uncertain fate of Brazilian rupestrian grasslands. Biodivers Conserv 27: 2587-2603.

FERNANDES GW, SANTOS R, BARBOSA NPU, ALMEIDA HA, CARVALHO $V$ \& ANGRISANO P. 2015. Occurrence of non-native and exotic plants in restored areas of rupestrian grasslands. Planta Daninha 33: 463-482.

FERNANDES GW, TOMA TSP, ANGRISANO P \& OVERBECK G. 2016. Challenges in the restoration of quartzitic and ironstone rupestrian grasslands. In: Fernandes GW (Ed). Ecology and conservation of mountaintop grasslands in Brazil. Switzerland, Springer, p. 449-477.

FILGUEIRAS TS, OLIVEIRA RC \& REIS PA. 2015. Melinis in Lista de Espécies da Flora do Brasil. Jardim Botânico do Rio de Janeiro. http://floradobrasil.jbrj.gov.br/jabot/ floradobrasil/FB25996. 16 Nov. 2017.

GIULIETTI AM, PIRANI JR \& HARLEY RM. 1997. EspinhaçO range region, eastern Brazil. In: Davis SD, Heywood VH, Herrera-MacBryde O, Villa-Lobos J and Hamilton AC (Eds). Centres of plant diversity: A guide and strategy for their conservation. Cambridge, WWF/IUCN, p. 397-404.

GOTELLI NJ \& ELLISON AM. 2004. Primer of ecological statistics. Massachusetts, Sinauer Associates Publishers, $510 \mathrm{p}$.

GRIME JP. 1977. Evidence for the existence of three primary strategies in plants and its relevance to ecological and evolutionary theory. Am Nat 111: 1169-1194.

GRIME JP \& PIERCE S. 2012 The evolutionary strategies that shape ecosystems. Chichester, Wiley-Blackwell, 244 p.

JACOBI CM, CARMO FF, VINCENT RC \& STHEMANN JR. 2007. Plant communities on ironstone outcrops: a diverse and endangered Brazilian ecosystem. Biodivers Conserv 16: 2185-220.

LE STRADIC S, BUISSON E \& FERNANDES GW. 2015. Vegetation composition and structure of some neotropical grasslands in Brazil. J Mount Sci 12: 864-877.

LEVINE JM, VILÁ M, D'ANTONIO CM, DUKES JS, GRIGULIS K \& LAVOREL S. 2003. Mechanisms underlying the impacts of exotic plant invasions. P Roy Soc Lond B Bio 270: 775-781.

MCINTYRE S, MARTIN TG, HEARD KM \& KINLOCH J. 2005. Plant traits predict impact of invading species: an analysis of herbaceous vegetation in the subtropics. Aust J Bot 53: 757-770.

NEGREIROS D, LE STRADIC S, FERNANDES GW \& RENNÓ HC. 2014. CSR analysis of plant functional types in highly diverse tropical grasslands of harsh environments. Plant Ecol 215: 379-388.

PEREIRA MRR, SOUZA GSF, SILVA JIC \& MATINS D. 2011. Densidades de plantas de Urochloa decumbens em convivência com Corymbia citriodora. Semina Cienc Agrar 32: 1803-1812. 
PÉREZ-HARGUINDEGUY N ET AL. 2013. New handbook for standardised measurement of plant functional traits worldwide. Aust J Bot 61: 167-234.

PIERCE S ET AL. 2017. A global method for calculating plant CSR ecological strategies applied across biomes worldwide. Funct Ecol 31: 444-457.

PIVELLO VR, SHIDA CN \& MEIRELLES ST. 1999. Alien grasses in Brazilian savannas: a threat to the biodiversity. Biodivers Conserv 8: 1281-1294.

QUINN GP \& KEOUGH MJ 2002. Experimental design and data analysis for biologists. New York, Cambridge University Press, $537 \mathrm{p}$.

REJMÁNEK M \& RICHARDSON DM. 1996. What attributes make some plant species more invasive? Ecology 77: 1655-1661.

SAINT-HILAIRE A. 2011. [1837]. Quadro geográfico da vegetação primitiva na Província de Minas Gerais. Belo Horizonte, Fino Traço, 54 p.

SERRANO-CÁRDENAS V, BALDERAS-AGUILAR P \& PELZ-MARÍN R. 2009. Querétaro: invasive weeds in natural areas in the semidesert of Mexico. In: van Devender TR, EspinosaGarcía FJ, Harper-Lore BL and Hubbard T (Eds). Invasive plants on the move: controlling them in North America, Arizona-Sonora Desert Museum, Tucson, Arizona, p. 157-164.

SHIRASUNA RT. 2015. Urochloa in Lista de Espécies da Flora do Brasil. Jardim Botânico do Rio de Janeiro. BFG. Growing knowledge: an overview of Seed Plant diversity in Brazil. Rodriguésia 66: 1085-1113.

SILVEIRA FAO ET AL. 2016. Ecology and evolution of the endangered campo rupestre: a neglected biodiversity conservation priority. Plant Soil 403: 129-152.

STOKES CA, MACDONALD GE, ADAMS CR \& LANGELAND KA. 2011. Seed biology and ecology of Natalgrass (Melinis repens). Weed Sci 59: 527-532.

VAN KLEUNEN M, WEBER E \& FISCHER M. 2010. A meta-analysis of trait differences between invasive and non-invasive plant species. Ecol Lett 13: 235-245.

VIANA PL \& LOMBARDI JA. 2007. Florística e caracterização dos campos rupestres sobre canga na Serra da Calçada, Minas Gerais, Brasil. Rodriguésia 58: 159-177.

VILÁ M ET AL. 2011. Ecological impacts of invasive alien plants: a meta-analysis of their effects on species communities and ecosystems. Ecology Letters 14: 702-708.

WRIGHT IJ ET AL. 2004. The worldwide leaf economics spectrum. Nature 428: 821-827.

\section{How to cite}

FERNANDES GW, TAMEIRÃO LBS, COSTA AR, RIBEIRO DG, NEVES MN, SOUZA E BRITO BG \& NEGREIROS D. 2021. Functional traits of three major invasive grasses in a threatened tropical mountain grassland. An Acad Bras Cienc 93: e20200119. DOI 10.1590/0001-3765202120200119.

Manuscript received on February 20, 2020;

accepted for publication on July 15, 2020

\section{GERALDO W. FERNANDES ${ }^{1}$}

https://orcid.org/0000-0003-1559-6049

\section{LUCAS B.S. TAMEIRÃ $0^{1}$}

https://orcid.org/0000-0003-2820-4753

\section{ADRIANA R. COSTA ${ }^{2}$}

https://orcid.org/0000-0002-1688-0714

\section{DANIELE G. RIBEIRO ${ }^{2}$}

https://orcid.org/0000-0002-8037-5925

\section{MICHELE N. NEVES}

https://orcid.org/0000-0003-2661-1558

\section{BETÂNIA G. SOUZA E BRITO'}

https://orcid.org/0000-0002-4738-8589

\section{DANIEL NEGREIROS 1,2}

https://orcid.org/0000-0002-4780-2284

${ }^{1}$ Universidade Federal de Minas Gerais, Ecologia Evolutiva e Biodiversidade, Departamento de Genética, Ecologia \& Evolução, ICB, Av. Pres. Antônio Carlos, 6627, Caixa Postal 486, Pampulha, 30161-970 Belo Horizonte, MG, Brazil

${ }^{2}$ Instituto de Ciências Biológicas e Saúde, Centro Universitário UNA, Rua dos Guajajaras, 175,

Centro, 30180-100 Belo Horizonte, MG, Brazil

\section{Correspondence to: Daniel Negreiros}

E-mail:negreiros.eco@gmail.com

\section{Author contributions}

GWF, LBST and DN: Conceptualization and methodology. LBST, ARC, DGR and MNN: Field sampling and laboratory measurements. DN: Data curation. GWF, LBST, ARC, DGR, MNN, BGSB and DN: Writing - review \& editing. All authors reviewed the results and approved the final version of the manuscript.

\section{(cc) BY}

